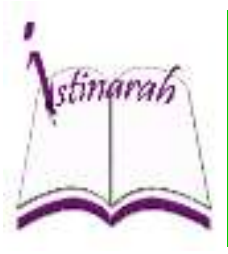

Istinarah: Riset Keagamaan, Sosial dan Budaya, Vol 1 (2), Desember 2019

ISSN :

(Print)

(Online)

Tersedia online di http://ecampus.iainbatusangkar.ac.id/ojs/index.php/istinarah/index

\title{
Manfaat Mengikuti Pengajian Rutin dalam Meningkatkan Kesadaran Beragama Masyarakat
}

\author{
Elva Oktavia *) \\ Institut Agama Islam Negeri \\ Batusangkar \\ Sumatera Barat, Indonesia \\ E-mail: elvaoktavia07@gmail.com
}

\section{Refika Mastanora}

Institut Agama Islam Negeri

Batusangkar

Sumatera Barat, Indonesia

E-mail:

refikamastanora@iainbatusangkar.ac.id
Abstrak: Pengajian rutin yang dilaksanakan di Masjid penting diadakan karena pada saat sekarang ini masyarakat tidak menghiraukan adanya pengajian. Penelitian ini menggunakan metode kualitatif deskriptif yang bertujuan untuk mengungkapkan kejadian atau fakta, keadaan, fenomena yang terjadi pada saat penelitian berlangsung. Informan penelitian adalah masyarakat Batubasa yang mengikuti pengajian. Teknik pengumpulan data yang peneliti gunakan adalah observasi, wawancara terstruktur, dengan metode analisis data berupa reduksi data, penyajian data, dan kesimpulan data, sedangkan keabsahan data menggunakan metode triangulasi sumber. Hasil penelitian menunjukkan bahwa manfaat dari mengikuti pengajian rutin yang diadakan di Masjid membuat masyarakat lebih meningkatkan kesadaran beragamanya dalam aspek wawasan dan pengetahuan, serta peningkatan aspek sikap.

Abstract: Regular recitals conducted at the mosque are important to be held because at present the community does not pay attention to the recitation. This research uses descriptive qualitative method that aims to reveal events or facts, circumstances, phenomena that occur when the research takes place. The research informants are Batubasa people who follow the recitation. Data collection techniques that researchers use are observation, structured interviews, with data analysis methods in the form of data reduction, data presentation, and data conclusions, while the validity of data using source triangulation methods. The results of the study showed that the benefits of attending routine recitals held at the mosque made the community increase their diversity awareness in the aspects of insight and knowledge, as well as in the attitude aspect.

Kata Kunci : Pengajian, Kesadaran beragama, Masyarakat. 


\section{PENDAHULUAN}

Pengajian agama merupakan salah satu bentuk kegiatan dakwah atau tabligh, karena di dalam pengajian itu sendiri tidak lepas dari usaha penyampaian ajaran-ajaran Islam dalam rangka mengajak atau membina umat manusia untuk senantiasa berada di jalan Islam, sehingga tercapai kedamaian dan kebahagiaan di dunia dan di akhirat. Pengajian merupakan salah salah satu kegiatan keagamaan dalam Islam. Pengajian tidak hanya dilakukan oleh orang-orang tertentu, seperti santri dan siswa namun pengajian juga diikuti oleh Bapakbapak, ibu-ibu, remaja dan anak-anak serta untuk semua kalangan. Pada umumnya, di dalam pengajian dibahas tentang ajaran-ajaran Islam dan penjelasannya, seperti muamalah, aqidah akhlak, tauhid dan masih banyak lagi ajaran Islam lainnya. Bagi sebagian muslim, pengajian juga merupakan kebutuhan seseorang untuk bisa mendapatkan ajaran-ajaran Islam yang baik dan benar. Sekaligus dijadikan sebagai sarana komunikasi dan sosialisasi.

Dakwah Islam atau pengajian di lingkungan masyarakat merupakan upaya untuk memenuhi kebutuhan rohani masyarakat, sehingga ada keseimbangan antara kebutuhan rohani dan kebutuhan jasmani masyarakat yang berada di Nagari Batubasa.

Pengajian rutinan di Masjid Baburahim Batubasa dilaksanakan setiap hari Jum'at malam setelah shalat isya berjamaah. Waktu pengajiannya berdurasi selama satu jam setengah. Metode yang digunakan dalam pengajian tersebut adalah ceramah. Para penceramah atau ustadz yang memberikan materi didatangkan dari dalam maupun dari luar Nagari Batubasa, diantaranya seperti Miftah Nofi, Tabareda, dan Yunius.

Pengajian rutinan ini diikuti oleh masyarakat Batubasa. Tujuan pengajian rutinan yang dilaksanakan di masjid Baburahim Batubasa adalah terpenuhinya kebutuhan spiritual agama, meningkatkan pemahaman agama dan menambah wawasan masyarakat, dan juga meningkatkan kesadaran masyarakat tentang kehidupan beragama dalam aspek ilmu pengetahuan dan juga dalam aspek sikap seperti cara bertutur kata yang baik dengan masyarakat yang lain, menghormati orang lain. Kegiatan 
tausiyah ini diharapkan tidak hanya dirasakan ketika berada di dalam masjid, tetapi di luar masjid bisa mempraktekkan langsung kepada orang lain, terutama dilakalangan masyarakat. Selain itu, kegiatan pengajian ini penting diadakan karena dikalangan masyarakat saat ini tidak memahami pentingnya kesadaran beragama di masyarakat, seperti minimnya ilmu tentang kaidah agama atau pengetahuan agama, dan juga cara bersikap kepada orng lain sehingga mereka tidak dapat dan sulit untuk mengamalkannya. Selain itu, pengajian rutinan ini juga bertujuan untuk membangun kesadaran beragama masyarakat baik dalam aspek pengetahuan maupun dalam aspek sikap di Nagari Batubasa.

\section{Kesadaran} beragama menggambarkan sisi batin seseorang yang terkait dengan sesuatu yang sakral. Sikap keagamaan merupakan suatu keadaan yang ada dalam diri seseorang yang mendorongnya untuk bertingkah laku sesuai dengan ketaatannya pada agama yang dianut. Jadi sikap keagamaan merupakan integrasi secara kompleks antara pengetahuan, perasaan serta tindak keagamaan dalam diri seseorang
( Sururin. $2004: 7$ ).

Kesadaran beragama yang dimaksud dalam penelitian ini meliputi rasa keagamaan, pengalaman ketuhanan, keimanan, sikap dan tingkah laku keagamaan yang terorganisasi dalam sistem mental dalam kepribadian. Agama melibatkan seluruh fungsi jiwa raga manusia, maka kesadaran beragamapun mencapai aspek kognitif, afektif dan motorik. Hal ini yang dimaksud dalam aspek motorik adalah aspek yang berupa perilaku keagamaan yang dilakukan seseorang dalam beragama seperti melaksanakn sholat tepat pada waktunya, dan menunaikan ibadah puasa.

Berdasarkan pengamatan awal peneliti tidak semua masyarakat yang datang ke masjid untuk mendengarkan pengajian atau ceramah, tetapi sebagian dari mereka hanya untuk mengisi waktu kosong saja, dan juga diantara masyarakat lebih banyak mengutamakan pekerjaannya dari pada ke masjid untuk mengikuti pengajian. Melalui wawancara yang telah dilakukan kepada Bapak Jamal salah seorang masyarakat yang mengikuti pengajian rutin mingguan, mengatakan 
bahwa ceramah yang disampaikan ustadz tidak terlalu menarik bagi saya, dan membuat saya bosan.

Mengenai hal itu, peneliti tertarik untuk meneliti manfaat mengikuti pengajian rutin terhadap kesadaran beragama masyarakat di Nagari Batubasa, karena menurut peneliti hal ini harus dicari solusi agar masyarakat meningkatkan kesadaran beragama melalui pengajian rutin yang dilakukan di masjid Baburahim Nagari Batubasa.

\section{METODE}

Jenis penelitian yang digunakan dalam penelitian ini adalah penelitian kualitatif yang menggunakan pendekatan deskriptif yang bertujuan untuk mengungkapkan kejadian atau fakta, keadaan, fenomena yang terjadi saat penelitian berlangsung dengan menyuguhkan apa yang sebenarnya terjadi.

\section{Menurut Moleong (2005:4),} pendekatan deskriptif kualitatif adalah pendekatan penelitian dimana data-data yang dikumpulkan berupa kata-kata, gambar, dan bukan angka. Data-data tersebut dapat diperoleh dari hasil wawancara, catatan lapangan, foto, vidio tape, dokumentasi pribadi, dan catatan.

Penelitian ini dilakukan di Nagari Batubasa, dimana kurangnya tingkat keasadaran beragama di masyarakat, dan kurangnya ilmu pengetahuan tentang agama di masyarakat, oleh karena itu peneliti bertujuan untuk memberikan pengetahuan yang dapat menumbuhkan tingkat kesadaran beragama di masyarakat Nagari Batubasa.

Pada penelitian kualitatif, peneliti memiliki kedudukan khusus, yaitu sebagai perencana, pelaksana pengumpulan data, analisis, penafsiran data, serta pelapor hasil penelitiannya (Moleong, 2010 :168). Kedudukan peneliti tersebut menjadikan peneliti sebagai key instrument atau instrumen kunci yang mengumpulkan data berdasarkan kriteria yang dipahami.

Penelitian ini menggunakan metode observasi, dan wawancara, sehingga peneliti membutuhkan instrumen penelitian seperti pedoman wawancara, kamera atau alat perekam lainnya, dan alat tulis. Sumber data penelitian terdiri dari sumber data primer dan sumber data sekunder.

Data sekunder merupakan pendekatan penelitian yang 
menggunakan data-data yang telah ada, selanjutnya dilakukan proses analisa dan interpretasi terhadap data-data tersebut sesuai dengan tujuan penelitian. Dalam penelitian ini data sekundernya peneliti peroleh dari catatan pengurus masjid dalam melaksanakan kegiatan pengajian, juga meminta file atau dokumen dari pengurus masjid Baburahim Batubasa.

Teknik pengumpulan data dalam penelitian ini menggunakann teknik wawancara, observasi lapangan (pengamatan), dan dokumentasi. Triangulasi adalah teknik keabsahan data yang memanfaatkan sesuatu yang lain untuk keperluan pengecekan atau sebagai pembanding data (Sugiono,2008:30). Menurut Patton ada tiga macam triangulasi yang dapat digunakan dalam penelitiannya antaranya :

Triangulasi sumber yaitu pemerikasaan sumber yang memanfaatkan jenis sumber data yang berbeda-beda untuk menggali data yang sejenis.

Triangulasi metode Yaitu pemeriksaan yang menekankan pada penggunakan metode pengumpulan data yang berbeda dan bahkan jenis untuk diusahakan mengarah pada sumber data yang sama untuk menguji kemantapan informasi.

$\begin{array}{ccr}\text { Triangulasi } & \text { teori } & \text { Yaitu } \\ \text { pemeriksaan } & \text { data } & \text { dengan }\end{array}$
menggunakan perspektif lebih dari satu teori dalam membahas permasalahan yang dikaji (Moleong,2005:331). Dalam penelitian ini, peneliti menggunakan triangulasi sumber, karena menurut peneliti sendiri dalam pemeriksaan sumber yang memanfaatkan jenis sumber data yang berbeda untuk menggali data yang sejenis, peneliti melakukan triangulasi sumber meliputi data diantara informan,buku,dakumentasi foto, dan lain-lain.

\section{HASIL DAN PEMBAHASAN}

Berdasarkan hasil penelitian terkait dengan manfaat mengikuti pengajian rutin dalam meningkatkan kesadaran beragama masyarakat di Nagari Batubsa, Peneliti menguraikannya sebagai berikut:

Temuan satu: Manfaat mengikuti pengajian rutin untuk meningkatkan kesadaran beragama masyarakat dalam aspek pengetahuan agama.

Adanya pengajian yang diadakan di Masjid Baburahim Batubasa 
memberikan manfaat kepada jamaah yang menghadirinya dimulai dari perubahan sikap dari jamaah itu sendiri - Jamaah mengetahui bahwa adanya pengajian yang diadakan di Masjid melalui himbawan dari pengurus Masjid melalui alat pengeras suara, tujuan dari masyarakat untuk mengikuti pengajian dikarenakan bahwa wawasan mengenai agama masih kurang, dan lebih ingin meningkatkan lagi ilmu agama yang sudah mereka miliki agar bisa dipraktekkan langsung kepada sanak saudara dan juga keluarga. Berkaitan dengan materi yang disampaikan oleh ustadz sangat menarik bagi jamaah yang datang kaerena materinya tidak membosankan dan membuat jamaah paham dengan apa yang disampaikan oleh ustadz tersebut. Perubahan yang jamaah rasakan selamamengikuti pengajian di Masjid yaitu biasanya jamaah jarang melaksanakan sholat berjamaah di masjid, sekarang sudah mulai terbiasa melaksanakan sholat berjamaah di Masjid, yang bisanya tidak pernah mendengarkan pengajian ke Masjid sekarang sudah sering datang ke Masjid untuk mendengarkan ceramah, da dengan adsnya pengajian rutin ini dapat menambah wawasan masyarakat mengenai ilmu agama. Bagi masyarakat sendiri materi yang diberikan ustadz bedasarkan fenomena yang terjadi saat sekarang ini, materi yang dibahas selalu meteri yang terbaru. Bagi masyarakat Batubasa sendiri pengajian yang diadakan di Masjid perlu lebih dikembangkan lagi agar tidak hanya masyarakat yang ad di Batubasa saja yang menghadirinya tetapi orang yang berada di luar Batubasa juga bisa mengahadirinya.

Temuan dua: Manfaat mengikuti pengajian rutin untuk meningkatkan kesadaran beragama masyarakat dalam aspek sikap.

Berdasarkan dari temuan yang peneliti lakukan dari manfaat mengikuti pengajian dari aspek sikap masyarakat merasakan bahwa sikap mereka menjadi lebih baik mulai dari perubahan seperti, cara bergaul masyarakat dengan orang lain menjadi lebih baik, cara bertutur kata menjadi lembut, lebih menghargai orang lain, sikap yank eras dulunya sekarang sudah melunak karena setelah mengikuti pengajian di Masjid.

Masyarakat sangat merasakan sekali perubahan di dalam dirinya 
karena mereka lebih memilih untuk lebih mendekatkan diri kepada Allah dari pada duduk di warung yang ridak ada manfaat bagi dirinya sendiri. Pengajian yang diadakan di Masjid membuat masyarakat betah untuk mendengarkannya karena ilmu nyang didapat juga banyak manfaatnya, masyarakat atau jamaah yang mengikuti pengajian tidak langsung merasakan perubahan di dalam dirinya melainkan melalui tahapan yang mereka jalani, ada yang merasakan perubahan setelah tiga minggu mengikutipengajianj, adanya yang mearsaajkan perubahan setelah berbulan- bulan untuk mengikuti pengajian, semua yang mereka rasakan jauh lebih bermanfaat terutama bagi diri jamah sendiri.

\section{KESIMPULAN}

Berdasarkan temuan peneliti di atas maka peneliti dapat menyimpulkan bahwa:

Manfaat mengikuti pengajian rutin untuk meningkatkan kesadaran beragama masyarakat dalam aspek pengetahuan agama seperti cara beribadah dengan baik, tata cara mendekatkan diri kepada Allah dan juga masyarakat merasa hatinya lebih tentram dan tenang saat mendengarkan ceramah yang diberikan oleh ustadz, dan yang mendorong jamaah untuk datang menghadiri pengajian yang diadakan di Masjid yaitu diri sendiri karena tujuan jamaah untuk mengikuti pengajian di Masjid ingin menambah wawasan pengetahuan agama yang sudah jamaah miliki dan ingin memperdalam lagi ilmu seputar dengan agama islam guna untuk dipraktekkan langsung di lapangan seperti kepada keluarga dan juga kepada orang sekitarnya. Selama jamaah mengikuti pengajian di Masjid jamaah merasa tidak jenuh karena materi yang diberikan oleh ustadz seputar fenomena yang sedang terjadi membuat masyarakat tidak ketinggalan dengan fenomena tersebut, materi yang disampaikan juga berhubungan dengan beribadah kepada Allah seperti mengerjakan sholat, zakat dan lain sebagainya.

Manfaat mengikuti pengajian rutin untuk meningkatkan kesadaran beragama masyarakat dalam aspek sikap, yakni masyarakat yang mengikuti pengajian yang diadakan di Masjid membuat masyarakat menjadi 
orang yang lebih sabar dan lebih taat kepada Allah dari pada yang sebelumnya dan lebih ingin mendekatkan diri kepada Allah dari pada berkumpul yang tidak ada manfaatnya. Perubahan sikap yang jamaah rasakan seperti bertutur kata menjadi lebih baik, lebih menghargai orang lain saat berbicara, dan lebih suka bergaul dengan masyarakat setempat dan lebih meningkatkan tegur sapa dengan sesama masyarakat disekitarnya. Jamaah lebih bersyukur dengan adanya pengajian yang diadakan di masjid karena bisa merubah hidup dan perilaku dari jamaah sebelum mengikuti pengajian dan setelah mengikuti pengajian di Masjid.

\section{REFERENSI}

Abdullah Aidid, 2006. Akhlak, Yogyakarta: Penyiaran Islam, Abdullah, Yatim.2007.Studi Akhlaq dalam Perspektif Al-Qur'an. Jakarta: Amzah.

Ahmad Amin, 2004. Ethika (Ilmu Akhlak), Terjemahan Ma'ruf , Jakarta, Bulan Bintang.

Ahmad D Marimba, 1980. Pengantar Filsafat Pendidikan Islam,
(Bandung: al-Ma arif,), cet IV.

Ali Mustafa Yaqub. 2000.Sejarah dan Metode Dakwah Nabi, (Pejaten Barat: Pustaka Firdaus,)

Aminuddin, dkk, Pendidikan Agama Islam Untuk Perguruan Tinggi, (Bogor: Ghalia Indonesia, 2005).

Choiruddin Hadiri, Akhlak dan Adab Islam, (Jakarta: PT Bhuana Ilmu Populer, 2015).

Doni Koesuma A, 2007. Pendidikan Karakter, Strategi Mendidik Anak di Zaman global, Jakarta: Grasindo.

Jurnal Komunikasi Pendidikan, Vol2 No1, Januari 2018. Jurnal Mudarrisuna, Volume 4, Nomor 2 (Juli - Desember 2014).

Mahmud Yunus, 1984. Akhlak, (Jakarta: Hidakarya Agung,).

M. Munir, 2009. Metode Dakwah, Cet. Ke-3, Jakarta: Kencana.

Moloeng, Lexy, 2004. Metodologi Penelitian Kualitatif, Edisi Revisi, (Bandung: Rosdakarya,)

Rahmat djatnika, 2005, Sistem Ethika Islami (Akhlak Mulia), Pustaka Panjimas, Jakarta.

Samsul Munir Amin, 2016 Ilmu Akhlak, Jakarta: Amzah.

Sarwono, S. (2011). Psikologi Remaja. 
Jakarta: PT. Rajagrafindo

Persada.

Wahyu Ilaihi, 2010. Komunikasi Dakwah, Bandung: PT. Remaja Rosda Karya.

Wahidin Saputra, 2012. Pengantar

Ilmu dakwah,(Jakarta: Raja

Gafindo Persada,).

Wirawan, S. Psikologi Remaja, Jakarta: Raja Grafindo Persada, 2002 